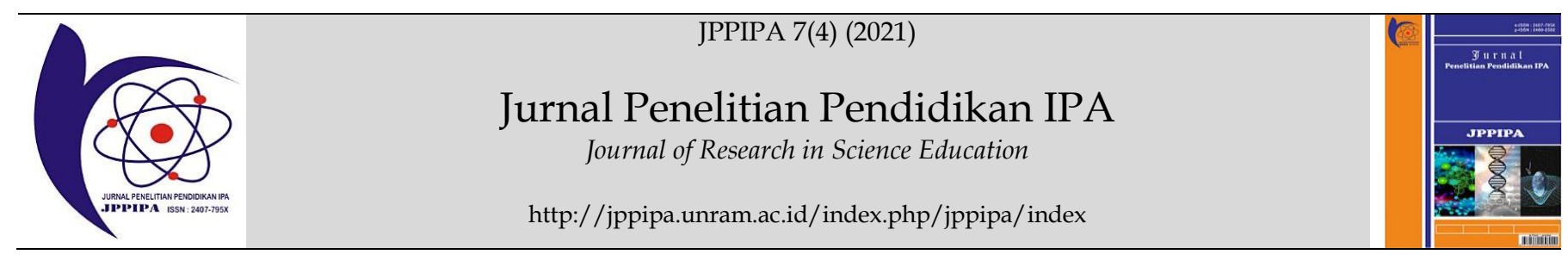

\title{
The Development of E-Student Worksheet on Environmental Pollution to Improve Critical Thinking Skills of Junior High School Students
}

\author{
Sri Wahyuni ${ }^{*}$, Lum'atul Khoirot Rizki1, Aris Singgih Budiarso', Pramudya Dwi Aristya Putra ${ }^{1}$, Erlia \\ Narulita $^{2}$
}

${ }^{1}$ Departement of Science Education, Faculty of Teacher Training and Education, University of Jember, Indonesia.

${ }^{2}$ Departement of Biology Education, Faculty of Teacher Training and Education, University of Jember, Indonesia.

\section{DOI: $10.29303 /$ ippipa.v7i4.870}

\section{Article Info}

Received : August 11th, 2021

Revised : September $13^{\text {th }}, 2021$

Accepted: October $14^{\text {th }}, 2021$

\begin{abstract}
This study purposed to develop an E-student worksheet on environmental pollution material to improve the critical thinking skills of junior high school students. Estudent worksheet is an electronic-based student worksheet that utilizes the internet in its application. E-student worksheets can create various kinds of visual and audiovisual content to train and assist students in finding concepts through the learning process. The development research method used a 4-D model, but only three stages were carried out: defining, designing, and developing. This research was conducted on seventh-grade students at SMPIT Al Ghozali Jember. The instruments used in this study were validation sheets, learning implementation sheets, critical thinking skills tests, and student response questionnaires. The results of this study indicated that the E-student worksheet had very valid criteria with a value of $94 \%$. The implementation of learning showed very high criteria with a value of $92 \%$. The effectiveness of learning had effective criteria with an average N-gain value of 0.70 , and student responses had a good criterion, with a value of $77.3 \%$. It can be concluded that the E-student worksheet on environmental pollution material could improve students' critical thinking skills in science learning in junior high school.
\end{abstract}

Keywords: E-Student Worksheet; Critical Thinking skills; Environmental Pollution

Citation: Wahyuni, S., Rizki, L., Budiarso, A., Putra, P., \& Narulita, E. (2021). The Development of E-Student Worksheet on Environmental Pollution to Improve Critical Thinking Skills of Junior High School Students. Jurnal Penelitian Pendidikan IPA, 7(4), 723-728. doi:https://doi.org/10.29303/ippipa.v7i4.870

\section{Introduction}

Sciences study natural phenomena that include living and non-living things in life (Rahayu et al., 2012). Science learning has very complex characteristics because it requires critical thinking skills in analyzing a problem (Rahayuni, 2016). In the application, many students still have difficulty understanding abstract material due to the lack of students' critical thinking ability (Awalsyah et al. 1., 2018; Mulyadi et al. 1., 2016).

Critical thinking skills are a process of thinking deeply about information to obtain accurate conclusions through investigation, exploration, experimentation, and others in which it can build students' knowledge significantly (Wahyuni et al., 2019). Critical thinking skills can occur because students face complex problems, where the problem will be a challenge for students to use their various abilities, such as analyzing and conveying arguments, giving classifications, providing evidence, reasoning, analyzing the meaning of an opinion, and the ability to draw conclusions. (Afifah \& Nurfalah, 2019).

Students' critical thinking skills are important to develop in the learning process because they are the 
basic in understanding science learning concepts (Dewi et al., 2016). The ability to think critically is very important for students because it can help students to think rationally in overcoming problems in everyday life (Hidayat et al., 2019). In addition, critical thinking skills can also be used to solve problems. It can be taken into consideration in making the right decisions (Wahyuni, 2015).

Based on the results of observations at school, students' critical thinking skills were not as expected, or it could be said that critical thinking skills were still relatively low. According to Utomo et al. (2020) stated that the decline in student achievement in science learning in Indonesia was based on the results of the TIMSS (Trends in International Mathematics and Science Study) assessment program in 2011, which reported that science learning achievement from 42 participating countries, Indonesia was ranked 40 or number 2 from below. This statement is supported by the statement of Utomo et al. (2018), which states that the achievement score is included in the cognitive domain, which includes knowledge, application, and reasoning with 406 points from the center of the TIMSS 500 scale. This Result shows that students' abilities in the realm of reasoning are still in the low category, which is $45.7 \%$ of students experienced reading errors so that they were wrong in giving answers.

The low critical thinking ability could be caused by several things, including media and learning resources that have not been used optimally in the application of learning in the classroom (Triono \& Santoso, 2018). According to Nuryanti et al. (2018), students' low critical thinking ability was also caused because students were less familiar with active learning and could not maximize their thinking potential. In addition, teachers could still optimally integrate critical thinking into the learning process (Choy \& Oo, 2012).

One of the problems in the learning process that is often faced by students related to critical thinking is the topic of environmental pollution. Teachers in environmental pollution have not trained the learning process and evaluation questions to develop critical thinking skills (Supriatna, 2019). Meanwhile, the learning process carried out is generally still teachercentered, so it cannot teach students concretely material about the complexity of problems in environmental pollution. It could be caused that students do not understand the concept (Assa et al., 2018).

According to Sari \& Bharata (2017), the process of understanding the concept will be better if it is guided by the activity steps contained in the Student Worksheet (student worksheet). A student worksheet is one media that students can use as a guide in conducting investigation activities or solving problems (Fitriani et al., 2017). Through this student worksheet, the learning process could improve the knowledge and critical thinking skills. Students will remember not only facts and events but also the results of self-discovery, a science concept. Additionally, critical thinking skills can increase (Firdaus \& Wilujeng, 2018).

Several research efforts have been carried out, such as the research conducted by Firdaus \& Wilujeng (2018), which developed the student worksheet with the theme "Gunung Meletus." The results of the study stated that there was an increase in students' critical thinking skills who were in the medium category with a score of 0.43 and received a score of 0.43 for positive student response. Then the research was conducted by Sari \& Bharata (2017) by developing a student worksheet on circle material, with the results of his research stating that students' critical thinking skills increased after using student worksheets in learning with all critical thinking indicators increasing. This Result shows that student worksheets can improve students' critical thinking skills.

However, those efforts have only used conventional student worksheets. It has never used Estudent worksheets or electronic student worksheets as media used in learning. Where in online learning (On the Network) during the current Covid 19 pandemic, the E- student worksheet is necessary to use. Using the E- student worksheet as a learning medium connects time and space limitations (Ferdiana, 2020). Based on that analysis, this study developing E- student worksheet to improve the critical thinking skills of junior high school students. According to Asma et al. 1. (2020), the use of the E- student worksheet was an interactive media addressed to help teachers more easily in the classroom. Students can also learn happily without feeling bored. Chinedu et al. (2015) stated that E- student worksheet was an innovative learning tool to support learning objectives. Thus E- student worksheets can be an alternative teaching material that can help students be more active in learning activities to improve critical thinking skills. One of the websites that facilitates the creation of E- student worksheets is liveworksheet.com which can be accessed for free by teachers. The advantage of using an E-student worksheet can be directly sent to the teacher when students have done it. Furthermore, E- student worksheet can contain images, audio, and videos that the teacher can design.

Based on the description of the problems above, the purpose of this research is to develop E- student worksheet on environmental pollution material to support the science learning process to improve the critical thinking skills of junior high school students in terms of validity, practicality, and effectiveness. 


\section{Method}

This research was development research (R\&D) because this research created a new product using the Thiagarajan 4-D development model. The development model was chosen because the stages used were suitable for developing the E-student worksheet. The stages in the 4-D development model are definition, design, development, and dissemination (Tanjung \& Nababan, 2018). However, this study only focused on the development stage because researchers have limited time and money.

The instruments used in this study were validation sheets, learning implementation sheets, critical thinking skills tests, and questionnaires of student responses. The validation test was calculated using the formulation (1), and the validation criteria are shown in Table 1.

$$
\mathrm{V}-a h=\frac{T S e}{T S h} \times 100 \%
$$

$\mathrm{V}$-ah = expert validation

Tse $=$ empiric score achieved

Tsh = expectation of the total score

Table 1. The validation criteria

\begin{tabular}{lll}
\hline No. & Aspect $(\%)$ & Kriteria Validitas \\
\hline 1. & $81<\mathrm{V} \leq 100$ & Extremely valid \\
2. & $61<\mathrm{V} \leq 80$ & Valid \\
3. & $41<\mathrm{V} \leq 60$ & Lack of valid \\
4. & $0<\mathrm{V} \leq 40$ & Not valid \\
\hline
\end{tabular}

(Akbar, 2011)

The Practicality data is extracted from learning implementation. The Result of the learning implementation was consulted in Table 2.

Table 2. Criteria of learning implementation

\begin{tabular}{lll}
\hline No & Aspect $(\%)$ & Criteria \\
\hline 1 & $80.1-100$ & Very high \\
2 & $60.1-80$ & High \\
3 & $40.1-60$ & Moderate \\
4 & $20.1-40$ & Low \\
5 & $0-20$ & Very low \\
\hline
\end{tabular}

(Akbar, 2011)

Presentation of the learning implementation was calculated using the formulation (2)

$$
(p)=\frac{\Sigma x}{n} \times 100 \%
$$

$\mathrm{P}=$ = percentage of the implementation

$\Sigma \mathrm{x} \quad=$ amount of item implemented

$\mathrm{n} \quad=$ amount of question items
Data on the effectiveness of the E- student worksheet were obtained from the normalized gain average score (N-gain) and student responses to the Estudent worksheet. The N-gain was calculated using the formulation (3), and the Result was consulted in Table 3.

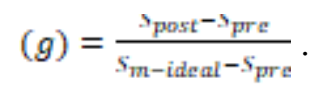

$<\mathrm{g}>\quad=$ Avarege score gain normalized

Spost = Avarage of student's final score

Spre = Avarage of student's initial score

Sm-ideal $=$ Maximum score

Table 3. Category Scale Average Score N-gain

\begin{tabular}{lll}
\hline No & Value $<\mathrm{g}>$ & Criteria \\
\hline 1 & $<\mathrm{g}>\geq 0.7$ & High \\
2 & $0.3<\mathrm{g}><0.7$ & Moderate \\
3 & $<\mathrm{g}><0.3$ & Low \\
\hline
\end{tabular}

(Asyhari, 2015)

Furthermore, the data obtained from the distribution of student response questionnaires were processed by the percentage obtained using the formula (4).

$$
\mathrm{P}=\frac{\text { Skor item yang diperoleh }}{\text { Skor maksimum }} \times 100 \%
$$

After obtaining the percentage value, then the value obtained was categorized based on Table 4 .

Table 4. Student Response Questionnaire Score Criteria

\begin{tabular}{lll}
\hline No & Intervals $(\%)$ & Criteria \\
\hline 1 & $25-43.7$ & Not good \\
2 & $43.8-62.5$ & Moderate \\
3 & $62.6-81.25$ & good \\
4 & $81.26-100$ & Extremely good \\
\hline
\end{tabular}

(Akbar, 2016)

\section{Result and Discussion}

\section{Validation analysis}

In this study, the product developed by the researcher was E- student worksheet. In the development of E- student worksheet activities, several stages were carried out to obtain an E-student worksheet with the topic of environmental pollution. The Result was in the valid category. The product of the E-student worksheet is shown in Figure 1. 

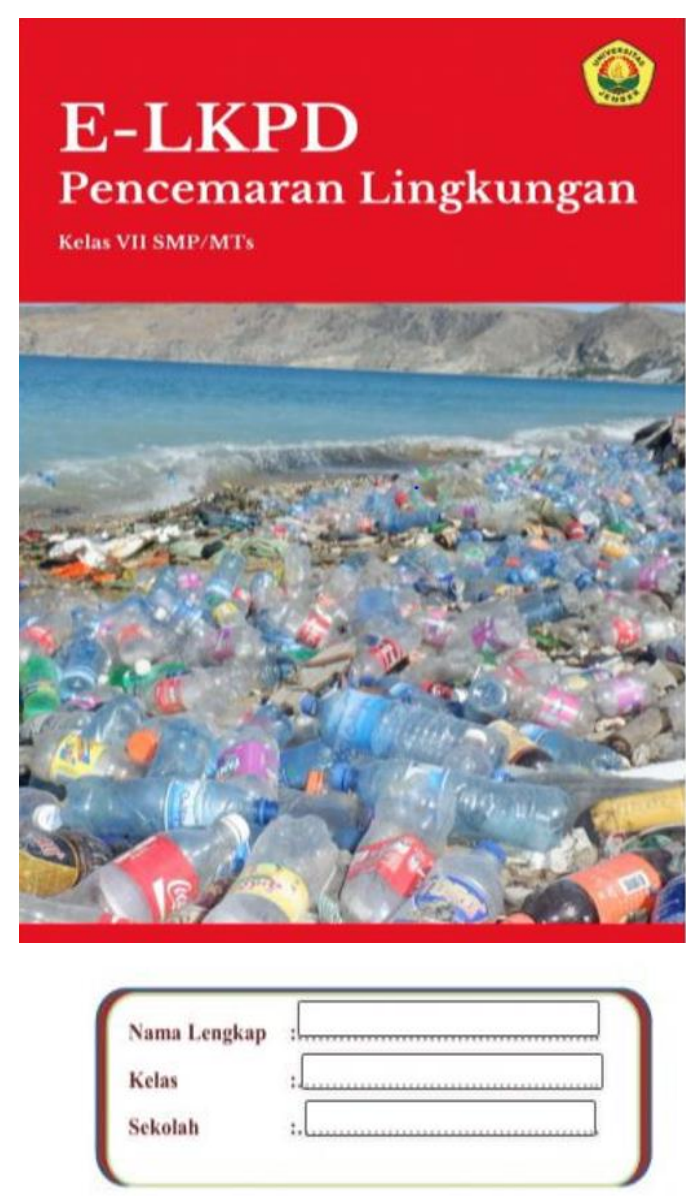

Bacalah petunjuk penggunaan E-LKPD sebelum mengerjakannya!

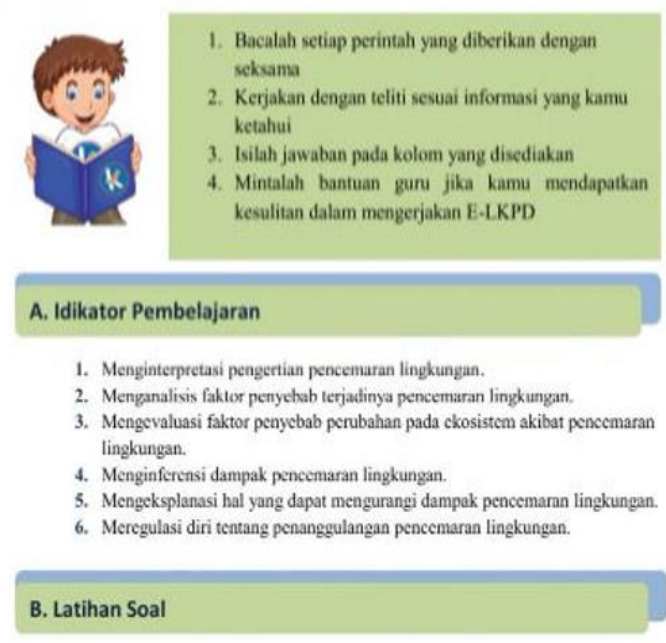

Figure 1. Cover Description and the content of Estudent worksheet

At this stage, the validation process was carried out by three experts, namely media experts, material experts, and users. The results of the validator's assessment of E- student worksheet products on environmental pollution materials to improve critical thinking skills in junior high school science learning are described in Table 5.
Table 5. The Result of E- student worksheet Validation

\begin{tabular}{llll}
\hline No. & Aspects & Values (\%) & Criteria \\
\hline 1. & Formats & 91 & Extrimely Valid \\
2. & Language & 93 & Extremely Valid \\
3. & Content & 99 & Extrimely Valid \\
4. & Grapics & 93 & Extrimely Valid \\
Rata-rata & 94 & Extrimely Valid \\
\hline
\end{tabular}

Based on the results of the analysis of the three validators, the average E- student worksheet validation value showed $94 \%$, and it is included in the Extremely valid criteria.

\section{Practical Analysis}

The practicality used in this research was the implementation of learning. After producing a valid Estudent worksheet then the development process was continued into the trial stage. The subjects of the development test were 20 students of class VIIC SMPIT $\mathrm{Al}$ Ghozali. The development test data obtained in this development research were data on the implementation of learning using an E-student worksheet on the topic of environmental pollution. Learning implementation data using the E-student worksheet was obtained through three observers who assessed the implementation of learning during the learning activities. The analysis of the implementation of learning can be seen in Table 6 .

Table 6. The Result of implantation learning

\begin{tabular}{llll}
\hline No & Activities & $\begin{array}{l}\text { Percenteg each } \\
\text { aspect }(\%)\end{array}$ & Criteria \\
\hline 1 & Introduction & 94 & Very high \\
2 & Learning core & 94 & Very high \\
3 & Closing & 88 & Very high \\
& Rata-rata & 92 & Very high \\
\hline
\end{tabular}

Based on the results in Table 6, it could be seen that the implementation of learning using the E-student worksheet showed an average percentage of the entire meeting of $92 \%$ so that the implementation of learning could be said to be very high.

\section{Effectiveness Analysis}

The effectiveness of the trial test in this development reseach produced the students' critical thinking skills after learning using the E- student worksheet. It was also student responses after using the E- student worksheet in learning activities. Students' critical thinking skills could be measured and assessed from the results of formative tests in accordance with the indicators of critical thinking skills using six critical thinking indicators adapted from Facione. The tests used were in the form of a pretest which was conducted before the use of the E- student worksheet, 
and a post-test which was conducted after the use of the E- student worksheet. Table 7 showed the Result of the students' critical thinking when they utilized the Estudent worksheet in their learning process.

Table 7. Critical Thinking Ability Test Results

\begin{tabular}{lllll}
\hline Components & Pretest & $\begin{array}{l}\text { Post- } \\
\text { test }\end{array}$ & $\begin{array}{l}\text { N-gain } \\
<\mathrm{g}\rangle\end{array}$ & Criteria \\
\hline $\mathrm{N}$ & 20 & 20 & & \\
XMin & 10 & 65 & 0.70 & High \\
XMax & 50 & 95 & & \\
\hline
\end{tabular}

Based on Table 7 showed that the value of Ngain in class VII students was 0.70 . This Result could be interpreted as an increase in students' critical thinking skills in grade VII after using the E-student worksheet on environmental pollution with high criteria. Furthermore, an analysis of student responses to the Estudent worksheet was carried out. Student responses were useful for measuring student responses after using the E- student worksheet. The results of the student response analysis can be seen in Table 8 .

Table 8. The Result of summarizing students' response

\begin{tabular}{llll}
\hline No. & Aspect & Presentation $(\%)$ & Category \\
\hline 1. & Interesting & 76 & Good \\
2. & Material & 76 & Good \\
3. & Language & 80 & Good \\
Avareage score & 77.3 & Good \\
\hline
\end{tabular}

Based on the results of the average student responses in Table 8 , the results of the average value of student responses showed a value of $77.3 \%$. This Result showed that the E- student worksheet received a good response from students and the percentage in each aspect, which indicates that the student's response was included in the good category.

\section{Conclusion}

The results of this development research could be concluded that E- student worksheet on environmental pollution improved students' critical thinking skills in science learning in junior high schools. This could be seen from 1) The results of the validation based on the three validators showed a value of $94 \%$ with very valid criteria, 2) The results of the analysis of the implementation of learning using E- Estudent worksheet showed a value of $94 \%$ with very high criteria, 3) The results of the effectiveness analysis after using the E- student worksheet showed an $\mathrm{N}$-gain value of 0.70 with high criteria, and student responses to the E- student worksheet showed a value of $77.3 \%$ with good criteria.

\section{Refrences}

Afifah, Y., \& Nurfalah, E. (2019). Kemampuan Berpikir Kritis Siswa Smp Negeri 1 Jenu Berdasarkan Langkah Facione Pada Pokok Bahasan Jajargenjang Dan Trapesium. Jurnal Riset Pembelajaran Matematika, 1(1), 37-42. Retrieved from

http://journal.unirow.ac.id/index.php/jrpm/ar ticle/view/65 [Indonesian]

Akbar, S. (2011). Curriculum Development and Social Science Learning. Yogyakarta: Cipta Media.

Asma, R., Asrial, A., \& Maison, M. (2020). Development of Interactive Electronic Student Worksheets on Electromagnetic Induction Based on Scientific Approaches. Jurnal Penelitian Pendidikan IPA, 6(2), 136-142. doi:https://doi.org/10.29303/ippipa.v6i2.387

Assa, E. P. A., Repi, R. A., \& Tanor, M. N. (2018). Pemanfaatan Miniatur Hutan Dengan Metode Inkuiri Pada Materi Pencemaran Lingkungan Terhadap Kemampuan Berpikir Kritis Peserta Didik Smp Negeri 1 Tondano. JSME (Jurnal Sains, Matematika \& Edukasi), 5(1), 1-5. Retrieved from: http://ejournal.unima.ac.id/index.php/jsme/ar ticle/view/286 [Indonesian]

Asyhari, A. (2015). Profil Peningkatan Kemampuan Literasi Sains Siswa Melalui Pembelajaran Saintifik. Jurnal Ilmiah Pendidikan Fisika Al-Biruni, $4(2)$,

179-191. https://doi.org/10.24042/jpifalbiruni.v4i2.91 [Indonesian]

Awalsyah, A., Sarwi, S., \& Sutikno, S. (2018). Pengembangan Lembar Kerja Siswa (Lks) Berbantuan Kvisoft Flipbook Maker Untuk Mengembangkan Keterampilan Ilmiah Siswa. UPEJ Unnes Physics Education Journal, 7(3), 28-35. https://doi.org/10.15294/upej.v7i3.27673 [Indonesian]

Chinedu, C. C., Olabiyi, O. S., \& Kamin, Y. (2015). Strategies for improving higher order thinking skills in teaching and learning of design and technology education.

https://ir.unilag.edu.ng/handle/123456789/615 $\underline{9}$

Choy, S. C., \& Oo, P. S. (2012). Reflective Thinking and Teaching Practices: A Precursor for Incorporating Critical Thinking into the Classroom?. Online Submission, 5(1), 167-182.

Dewi, M. R., Mudakir, I., \& Murdiyah, S. (2016). Pengaruh Model Pembelajaran Kolaboratif berbasis Lesson Study terhadap Kemampuan Berpikir Kritis Siswa. Jurnal Edukasi, 3(2), 29-33. https://doi.org/10.19184/jukasi.v3i2.3526 [Indonesian] 
Ferdiana, S. (2020). Persepsi Mahasiswa tentang Penggunaan Media Daring pada Program Studi S1 Ilmu Gizi Sekolah Tinggi Ilmu Kesehatan Surabaya selama Masa Pandemi Corona Virus Disease (COVID-19). Indonesian Journal of Science Learning, $\quad 1(1)$, 5-12. https://doi.org/10.15642/ijsl.v1i1.631

[Indonesian]

Firdaus, M., \& Wilujeng, I. (2018). Pengembangan LKPD inkuiri terbimbing untuk meningkatkan keterampilan berpikir kritis dan hasil belajar peserta didik. Jurnal Inovasi Pendidikan IPA, 4(1), 26-40.

doi:https://doi.org/10.21831/jipi.v4i1.5574 [Indonesian]

Fitriani, N., Gunawan, G., \& Sutrio, S. (2017). Berpikir Kreatif Dalam Fisika Dengan Pembelajaran Conceptual Understanding Procedures (CUPs) Berbantuan LKPD. Jurnal Pendidikan Fisika dan Teknologi, 3(1), 24-33. doi:http://dx.doi.org/10.29303/jpft.v3i1.319. [Indonesian]

Hidayat, F., Akbar, P., \& Bernard, M. (2019). Analisis Kemampuan Berfikir Kritis Matematik Serta Kemandiriaan Belajar Siswa Smp Terhadap Materi SPLDV. Journal on Education, 1(2), 515-523. https://doi.org/10.31004/joe.v1i2.106. [Indonesian]

Mulyadi, D., Wahyuni, S., \& Handayani, R. (2016). Pengembangan media flash flipbook untuk meningkatkan keterampilan berfikir kreatif siswa dalam pembelajaran ipa di smp. Jurnal pembelajaran fisika, 4(4), 296 - 301. Retrieved from https://jurnal.unej.ac.id/index.php/JPF/article $\angle$ view/2728. [Indonesian]

Nuryanti, L., Zubaidah, S., \& Diantoro, M. (2018). Analisis Kemampuan Berpikir Kritis Siswa SMP. Jurnal Pendidikan: Teori, Penelitian, dan Pengembangan, 3(2), 155-158. https://doi.org/10.17977/iptpp.v3i2.10490 [Indonesian]

Rahayu, P., Mulyani, S., \& Miswadi, S. S. (2012). Pengembangan Pembelajaran Ipa Terpadu Dengan Menggunakan Model Pembelajaran Problem Base Melalui Lesson Study. Jurnal Pendidikan IPA Indonesia, 1(1), Article 1. https://doi.org/10.15294/ipii.v1i1.2015 [Indonesian]

Rahayuni, G. (2016). Hubungan Keterampilan Berpikir Kritis Dan Literasi Sains Pada Pembelajaran Ipa Terpadu Dengan Model Pbm Dan Stm. Jurnal Penelitian dan Pembelajaran IPA, 2(2), 131-146. doi: http://dx.doi.org/10.30870/ippi.v2i2.926 [Indonesian]
Sari, D. P., \& Bharata, H. (2017). Pengembangan Student Worksheet Berbasis Inkuiri Terbimbing untuk Meningkatkan Kemampuan Berpikir Kritis Siswa. 5, 13.

Supriatna, A. (2019). Profil Kemampuan Berpikir Kritis Peserta Didik yang Proses Pembelajarannya Menggunakan Model Pembelajaran Concept Attainment dan Model Pembelajaran Inductive Thinking pada Materi Pencemaran Lingkungan. Bioedusiana, 4(2), 31-37. https://doi.org/10.34289/285226 [Indonesian]

Tanjung, H. S., \& Nababan, S. A. (2018). Pengembangan Perangkat Pembelajaran Matematika Berorientasi Model Pembelajaran Berbasis Masalah (Pbm) Untuk Meningkatkan Kemampuan Berpikir Kritis Siswa Sma Se-Kuala Nagan Raya Aceh. Genta Mulia: Jurnal Ilmiah Pendidikan, 9(2), Retrieved from:. https://www.ejournal.stkipbbm.ac.id/index.ph $\mathrm{p} / \mathrm{gm} /$ article/view/168 [Indonesian]

Triono, A., \& Santoso, S. (2018). The Effect Of Discovery Learning Model On Critical Thinking Ability In Thematic Learning. International Conference Education, Culture and Technology. 1(1), 95-98.

Utomo, A. P., Narulita, E., \& Billah, R. N. I. (2020). Penerapan model pembelajaran problem based learning berbasis socio-scientific issue (SSI) terhadap kemampuan berpikir kritis siswa SMP. JIPVA (Jurnal Pendidikan IPA Veteran), 4(2), 148159. https://doi.org/10.31331/jipva.v4i2.1259 [Indonesian]

Utomo, A. P., Yuana, K., Narulita, E., Fikri, K., \& Wahono, B. (2018). Students' Errors in Solving Science Reasoning-Domain of Trends in International Mathematics and Science Study (TIMSS). Jurnal Pendidikan IPA Indonesia, 7(1), 4853. https:// doi.org/10.15294/ipii.v7i1.11352

Wahyuni, S. (2015). Pengembangan Bahan Ajar IPA Untuk Meningkatkan Kemampuan Berpikir Kritis Siswa SMP. Prosiding: Seminar Nasional Fisika Dan Pendidikan Fisika, 6(6), Article 6. https://jurnal.fkip.uns.ac.id/index.php/prosfis1 Larticle/view/7857 [Indonesian]

Wahyuni, S., Sanjaya, I. G., Erman, \& Jatmiko, B. (2019). Edmodo-based blended learning model as an alternative of science learning to motivate and improve junior high school students' scientific critical thinking skills. International Journal of Emerging Technologies in Learning, 14(7), 98-110. https://doi.org/10.3991/ijet.v14i07.9980. 